\title{
The Effect of Organic and Inorganic Fertilizers on the Yield of Two Contrasting Soybean Varieties and Residual Nutrient Effects on a Subsequent Finger Millet Crop
}

\author{
Abebe Zerihun ${ }^{1, *}$ and Deressa Haile ${ }^{2}$ \\ 1 Bako Agricultural Research Center, P.O. Box 03, West Shoa, Ethiopia \\ 2 Deutsche Gesellschaft fur Internationale Zusammenarbeit (GIZ) GmbH, P.O. Box 100009, Addis Ababa, \\ Ethiopia; haile.deressa@giz.de \\ * Correspondence: baatiree@gmail.com; Tel.: +251-913-372-899
}

Academic Editor: Francesco Montemurro

Received: 5 April 2017; Accepted: 17 May 2017; Published: 12 June 2017

\begin{abstract}
The problems of low soil fertility resulting from continuous monocropping, crop residue removal and limited fertilizer use represent key challenges to produce surplus food for the ever increasing population of Ethiopia. However, the practices of crop rotation and integrated sources of fertilizer uses could potentially improve soil fertility and productivity. In 2012 and 2014, soybean with different trials consisting of two soybean varieties (Boshe and Ethio-ugozilavia), three levels of farm yard manure (FYM) $(3,6$ and $9 \mathrm{t} / \mathrm{ha})$ and three phosphorus levels $\left(8,16\right.$ and $\left.24 \mathrm{~kg} \mathrm{P} \mathrm{ha}^{-1}\right)$ were combined in $2 \times 3 \times 3$ factorial arrangements. Two soybean varieties receiving no fertilizer application followed by finger millet receiving a recommended rate $(20 \mathrm{~kg} \mathrm{P} / \mathrm{ha})$ were included. The experiment was laid out in a randomized complete block design with three replications. In 2013 and 2015, finger millet was planted on each soybean plot as per previous treatment arrangements to evaluate the effect of the precursor crop (soybean) and integrated fertilizer application on yield performance of the subsequent finger millet. Soil $\mathrm{pH}$, organic carbon, total nitrogen and available phosphorus before planting and after crop harvest of soybean in each year showed treatment differences. Both precursor crop and fertilizer application had a positive effect on soil fertility status and, hence, improved the performance of the subsequent finger millet. On the other hand, since the rainfall amount and distribution were different in the 2012 and 2014 seasons, the response of soybean varieties to applied fertilizers was significantly affected, and the correlation between soybean yield and annual rainfall was strongly positive. Use of an early maturing soybean variety (Boshe) with the lowest rates of organic and inorganic fertilizers gave significantly higher yield in 2012 (short rainy season) compared with other treatment combinations. In the 2014 cropping season, however, 'Ethio-ugozilavia' showed greater yield performance with the combined application of $3 \mathrm{t} \mathrm{FYM/ha} \mathrm{and} 1616 \mathrm{~kg} \mathrm{PP} /$ ha followed by $3 \mathrm{t} \mathrm{FYM} \mathrm{and} 88 \mathrm{~kg} \mathrm{P} / \mathrm{ha}$. Hence, it is recommended to use the 'Boshe' variety under a short rainy season and under a low soil fertility status, while variety the 'Ethio-ugozilavia' can be used under good rainy and soil fertility management conditions. Considering residual effects, the use of the early maturing soybean variety as a precursor with $3 \mathrm{t} \mathrm{FYM} /$ ha and $8-16,816 \mathrm{~kg} \mathrm{P} /$ ha during the short rainy season could enhance the yield of the subsequent finger millet. On the other hand, the use of the late maturing soybean variety as a precursor with higher organic fertilizer rates (6-9 t FYM/ha) resulted in a significant yield increase of the subsequent finger millet. The use of a late maturing variety of soybean with lower rates of organic manure resulted in a finger millet yield comparable to farmers' practice, indicating that this option can be adopted by smallholder farmers who cannot produce sufficient organic manure. This study showed that planting of finger millet after a soybean precursor crop even without fertilizer application could give better yield and economic benefits as it saves $70-85 \%$ of chemical fertilizer costs compared to the farmers' practice.
\end{abstract}


Keywords: soybean; finger millet; crop rotation; FYM; phosphorus; rainfall

\section{Introduction}

Declining soil fertility is a main reason for the slow growth in food production in Sub-Saharan Africa [1]. Low soil fertility due to monoculture cereal production systems is recognized as one of the major causes for declining per capita food production). A declining soil fertility is also an important bottleneck for smallholder cereal producers in central western parts of Ethiopia [2]. Continuous monocultures of cereals also result in reduction of yields and soil nutrients, particularly nitrogen $[3,4]$. Declining yield and soil fertility as a result of continuous mono-cropping have also been reported for finger millet [5-7].

Crop rotation is considered to be a key cultural practice to avert the problem of mono-cropping by enhancing soil fertility and crop productivity. Legume-based crop rotations have positive effects on soil fertility because legumes fix $\mathrm{N}$ and contribute nutrients and carbon in addition to litter fall and residue decomposition [8,9]. According to Zerihun et al. [2], a 9-35\% yield advantage was gained due to crop rotation practices compared to the yield of mono-cropped maize. Another study showed that the effect of inoculated soybean as precursor crop resulted in a $15-21 \%$ yield increase of maize over the mono-cropped one [10]. However, the application of fertilizer to soybean significantly enhanced grain yield while at the same time increasing biomass that drops as litterfall and contributes to soil organic build up and fertility improvement [3]).

Studies show that rainfall and soil fertility variability are the main factors influencing the response of crops to applied nutrient sources. Tropical and sub-tropical soils are variable in terms of both physical and chemical properties, which affect crop responses to different fertilizer inputs. For instance, the spatial variability of soil organic carbon, total or available nitrogen, available phosphorus and soil $\mathrm{pH}$ are some of the factors [11]. The significant role and spatial variability of nitrogen and phosphorus highly affected crop responses [6]. In addition, appropriate rainfall amount and distribution not only enhance the yield, but also reduce year to year variability [12].

Soybean is a pulse crop with multiple food and economic advantages for small-scale farmers. It is used as food for home consumption, raw materials for local factories and feed for animal dairy or fattening farms [13]. In addition, soybean has the capacity to fix atmospheric nitrogen from the air through symbiosis with rhizobium bacteria and thus contributes to improved soil fertility when grown in rotation with cereals [13,14]. It also contributes to increased soil organic $\mathrm{N}$ and carbon through its fallen senescent leaves and below ground parts [15]. As a result, it has an additional advantage of reducing $\mathrm{N}$ fertilizer requirement for subsequent crops in a rotation. Therefore, soybean is an important crop with multiple benefits, which can be grown in rotation with cereals like maize, finger millet and sorghum.

Despite these advantages, the productivity of soybean is limited due to the lack of improved varieties and poor soil and crop management practices. As a result, smallholder farmer yield for the crop is far below the potential production. For instance, the national average yield of soybean varied from $1.8 \mathrm{t} \mathrm{ha}^{-1}$ in 2012 to $2.0 \mathrm{t} \mathrm{ha}^{-1}$ in 2013 while the potential yield obtained from on-station and on-farm research fields was 3.5 and $2.6 \mathrm{tha}^{-1}$, respectively [16]). Low soil nitrogen and phosphorus are among the major factors limiting production and productivity of legume crops. Legume plants that depend on biological $\mathrm{N}_{2}$ fixation for their $\mathrm{N}$ supply require more $\mathrm{P}$ than plants receiving fertilizer $\mathrm{N}$ since the reduction of atmospheric $\mathrm{N}$ by the nitrogenous system is a very energy-consuming process. Hence, the plants require more $\mathrm{P}$ and other nutrients for symbiotic $\mathrm{N}$ fixation than for general plant metabolism $[17,18]$. Nitrogen is the most important nutrient for crop production, and its deficiency occurs in most countries of the world [18].

Evidence shows that the use of organic fertilizers combined with inorganic sources enhances nutrient availability, optimizes the soil environment and improves crop productivity [1]. To this end, 
the appropriate combination of organic and inorganic fertilizers sources for the specific soil type is needed to improve the soil fertility and productivity of crops. The objective of this study was, therefore, to evaluate the effect of combined use of improved soybean varieties, organic fertilizer (farm yard manure) and inorganic phosphorus on the yield of soybean under variable rainfall and soil fertility conditions and to further evaluate the residual effect of soybean as a precursor with the combined fertilizer application yield performance of a subsequent finger millet crop.

\section{Materials and Methods}

The experiment was conducted at the Bako main research site for four (2012-2015) consecutive years. The experimental site is located in sub-humid areas of central Western Ethiopia, and it lies at a latitude of $9^{\circ} 6^{\prime} \mathrm{N}$, longitude of $37^{\circ} 9^{\prime} \mathrm{E}$ and $1650 \mathrm{~m}$ above sea level. It is a warm sub-humid climate with annual mean minimum and maximum air temperatures of $13.5^{\circ} \mathrm{C}$ and $29.7^{\circ} \mathrm{C}$, respectively. The area received average annual rainfall of $887 \mathrm{~mm}$ (2012), $1431 \mathrm{~mm}$ (2013), $1067 \mathrm{~mm}$ (2014) $\mathrm{mm}$ and $994 \mathrm{~mm}$ (2015) with maximum precipitation recorded in the months of May-August (Figure 1).

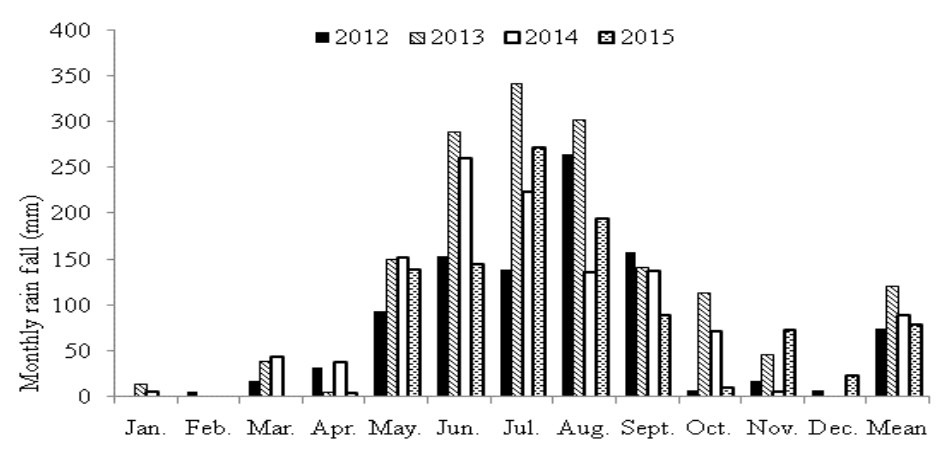

Figure 1. Mean monthly rainfall at of the Bako Agricultural Research Center, Ethiopia, 2012-2015.

The soil of the experimental site is reddish-brown, nitosol. It is an acidic soil with a pH range of 4.5-5.6. The area is a mixed farming zone and is one of the most important maize (Zea mays L.) growing belts in Ethiopia, and cultivations of tef (Eragrostis tef(zucc.) Trotter, finger millet (Eleusine coronata) common bean (Phaseolus vulgaris L.), sorghum (Sorghum bicolor L.), noug (Guizotia abyssinica Lf.) and soybean (Glycine max L.) are common. The cropping system of the area is predominantly maize-based mono-cropping with low soil fertility, which directly influences the production and productivity of the cultivated crops.

\subsection{Soil Sampling}

Initial composite soil samples were collected from a depth of 0-30 $\mathrm{cm}$ before planting the soybean trial in 2012 and 2014. Soil samples were also taken from each plot after soybean was harvested to assess changes in soil fertility status due to the effect of soybean precursor crop and integrated application of organic and inorganic fertilizers. Soil $\mathrm{pH}$ was measured using a digital $\mathrm{pH}\left(\mathrm{H}_{2} \mathrm{O}\right)$ meter. The Walkley-Black [19] method was followed for the determination of soil organic carbon $(\% \mathrm{OC})$, whereas the cation exchange capacity $(\mathrm{CEC}$, in centimol $(\mathrm{cmol}) / 100 \mathrm{~g}$ soil) was analyzed using ammonium acetate. Total nitrogen $(\% \mathrm{~N})$ and available phosphorus $\left(\mathrm{mg} \mathrm{kg}^{-1}\right.$ soil) were analyzed by the Kjeldahl (Jackson, 1958) and the Bray II ([20] methods, respectively).

The result of initial soil analysis showed that the $\mathrm{pH}$ was in the strongly acidic range as per the standard classification procedure by [21] (2008). Total nitrogen of the sites was highly variable and found in the low (2012) to medium (2014) range. The available phosphorus content of the soil was categorized under moderate range for both cropping seasons. Similar to soil nitrogen, the organic carbon content varied in each season, though it was in the medium range (Table 1). 
Table 1. Soil physico-chemical properties of the experimental area before soybean planting.

\begin{tabular}{|c|c|c|c|c|c|c|c|c|}
\hline Year & $\begin{array}{c}\mathrm{pH} \\
\left(\mathrm{H}_{2} \mathrm{O}\right)\end{array}$ & $P\left(\mathrm{mg} \mathrm{kg}^{-1}\right)$ & $\begin{array}{c}\text { Total N } \\
(\%)\end{array}$ & OC (\%) & CEC $\left(\mathrm{cmol} \mathrm{kg}^{-1}\right)$ & $\mathrm{K}\left(\mathrm{cmol} \mathrm{kg}^{-1}\right)$ & $\begin{array}{l}\text { Exch.Acidity } \\
\left(\mathrm{cmol} \mathrm{kg}^{-1}\right)\end{array}$ & Texture \\
\hline 2012 & 4.9 & 7.9 & 0.12 & 1.65 & 19.21 & 1.13 & 0.13 & Clay \\
\hline 2014 & 4.55 & 15.10 & 0.19 & 2.25 & 22.68 & 1.12 & 0.12 & Clay \\
\hline
\end{tabular}

\subsection{Experimental Procedures}

A two-year soybean-millet rotation, which was conducted twice (i.e., the same two-year rotation experiment was replicated twice over time, in 2012-2013 and in 2014-2015), in the same general location, in fields with a similar fertility and cropping history.

In the 2012 and 2014 cropping seasons, the soybean trial consisted of three factors, namely two soybean varieties (Boshe and Ethio ugozilavia), three levels of organic fertilizer (3, 6 and $9 \mathrm{t} / \mathrm{ha}$ farm yard manure (FYM)) and three levels of phosphorus fertilizer $(8,16$ and $24 \mathrm{~kg} \mathrm{P} / \mathrm{ha})$ in separate plots. These factors were combined in $2 \times 3 \times 3$ factorial arrangements and laid out in a randomized completed block design (RCBD) with three replications.

In addition two separate 'reference' trials were conducted consisting of: (A) a two-year soybean-millet rotation in which no fertilizer or amendment applications were applied in Year 1; and (B) a two year continuous millet-millet monoculture planting, in which recommended chemical fertilizer applications ( $20 \mathrm{~kg} \mathrm{P} / \mathrm{ha}$ ) were applied only during the first year of the two-year planting.

The Boshe variety is an early type (117-125 days to maturity), whereas Ethio-ugozilavia is a late type (145-154 days to maturity). The same experimental plots of a Year 1 for the two seasons (2012 and 2014) were maintained to further evaluate the effect of residual fertilizers and amendments applied during Year 1 of the rotation on the yield of millet (which was the second crop in the rotation). Therefore, the millet was planted in the second year of the rotation, in fields that in the previous year were planted with: (a) a previous soybean crop that received fertilizer or amendment applications as per treatment combinations; (b) a previous soybean crop that received no fertilizer or amendment applications; and (c) a previous millet crop that had received a recommended chemical fertilizer application. An improved variety of finger millet (Gute) was used as a test crop for all experimental plots. This variety has an erect growth habit and matures within 140-150 days. Its yield potential under research is $2-3.5 \mathrm{t} / \mathrm{h}$, whereas it provides $2-3.2 \mathrm{t} /$ ha under farmers' management.

The experimental plots for soybean trial were plowed three times at different time intervals starting from mid-May and leveled manually prior to the field layout. However, the plots maintained for the following millet planting were prepared by human labor without mixing soil of each experimental plot. Decomposed and air-dried FYM (20\% moisture content) was applied as per treatments and incorporated manually into the soil, one month before soybean planting. Phosphorus fertilizer in the form of di-ammonium phosphate (DAP) was applied at the time of planting. Each experimental plot had $3.2 \mathrm{~m} \times 3 \mathrm{~m}$ gross area and the distance between block was $1 \mathrm{~m}$, while the distance between plot was $50 \mathrm{~cm}$. The reference plots had also the same plot sizes with main soybean-millet rotation experimental plots and replicated three times. The spacing for soybean was $40 \mathrm{~cm}$ between rows and $10 \mathrm{~cm}$ between plants and planted on 10 June (2012) and 15 June (2015). On the other hand, the spacing for finger millet was $40 \mathrm{~cm}$ between rows and planting was done on 15 June (2013) and 10 June (2015) by drilling in the manually-prepared rows, and the population was thinned $5 \mathrm{~cm}$ between plants after seedlings emerged.

At the time of agronomic maturity, both crops were harvested from the net plot areas of $2.4 \mathrm{~m}$ $\times 3 \mathrm{~m}$ by excluding the border rows. The Boshe variety was first harvested at the end of October, while Ethio-ugozilavia was harvested after mid-November. Stand count at harvest was counted from the net plot area, six central rows. The grain yield of soybean and finger millet was measured using electronic balances. Grain yield was adjusted to standard moisture contents for soybean to $10 \%$, i.e., adjusted yield $=$ actual yield $\times 100-M / 100-\mathrm{D}$, where $\mathrm{M}$ is the measured moisture content. The Finger 
millet yield was sun and air dried for four days after threshing and before measuring the grain. Finally, yield data for both crops were subjected to analysis of variance using the GenStat-15 software. Means were separated using least significant value at the $p<0.05$ probability level. Sigma plot Version 10 was used to sketch bar graphs.

\section{Results}

The analysis of variance revealed that seasonal variations highly affected $(p<0.001)$ yield performance of soybean varieties in combination with the integrated fertilizer application (Table 2). These significant variations were due to high rainfall variability in each season and to the soil fertility dynamics of the experimental site. Therefore, comparison of treatment means was done for each cropping season individually. Even though the soybean varieties were significantly different in their yield performance, significant interactions were observed between the varieties and applications of FYM and P (Table 2).

Table 2. Combined ANOVA table for yield performance of soybean as affected by varieties, FYM and P fertilizers' application in the 2012 and 2014 cropping seasons at Bako, Ethiopia.

\begin{tabular}{|c|c|c|c|c|}
\hline Source of Variation & d.f. & Mean Square & Variance & F Probability \\
\hline Yr (Year) & 1 & $12,715,321$ & 53.34 & $<0.001$ \\
\hline SBv (Soybean varieties) & 1 & $2,899,072$ & 12.16 & $<0.001$ \\
\hline Farm Yard Manure(FYM) & 2 & 114,713 & 0.48 & 0.62 \\
\hline Phosphorus $(\mathrm{P})$ & 2 & 109,319 & 0.46 & 0.634 \\
\hline $\mathrm{Yr} * \mathrm{SBv}$ & 1 & 337,413 & 1.42 & 0.238 \\
\hline $\mathrm{Yr}^{*} \mathrm{FYM}$ & 2 & 248,703 & 1.04 & 0.358 \\
\hline $\mathrm{SBv} * \mathrm{FYM}$ & 2 & 439,259 & 1.84 & 0.166 \\
\hline $\mathrm{Yr} * \mathrm{P}$ & 2 & 329,063 & 1.38 & 0.258 \\
\hline $\mathrm{SBv}^{*} \mathrm{P}$ & 2 & 391,398 & 1.64 & 0.201 \\
\hline $\mathrm{FYM} * \mathrm{P}$ & 4 & 498,150 & 2.09 & 0.091 \\
\hline $\mathrm{Yr}^{*} \mathrm{SBV}^{*} \mathrm{FYM}$ & 2 & 211,381 & 0.89 & 0.417 \\
\hline $\mathrm{Yr} * \mathrm{SBV}^{*} \mathrm{P}$ & 2 & 371,160 & 1.56 & 0.218 \\
\hline $\mathrm{Yr}^{*} \mathrm{FYM} * \mathrm{P}$ & 4 & 164,138 & 0.69 & 0.602 \\
\hline $\mathrm{SBv} * \mathrm{FYM} * \mathrm{P}$ & 4 & 654,620 & 2.75 & 0.032 \\
\hline $\mathrm{Yr}^{*} \mathrm{SBv}{ }^{*} \mathrm{FYM}{ }^{*} \mathrm{P}$ & 4 & 122,135 & 0.51 & 0.727 \\
\hline Blocks & 2 & $1,991,103$ & 8.35 & $<0.001$ \\
\hline Residual & 70 & 238,403 & - & - \\
\hline Total & 107 & & - & - \\
\hline
\end{tabular}

Since seasonal variations significantly affected the performance of the crop, the overall mean for each season indicated that significantly less yield was obtained in the $2012(2060 \mathrm{~kg} / \mathrm{ha})$ season as compared to 2014 (2760 kg/ha). Overall, a 33\% yield reduction was observed in the short rainy season. The main reason for the yield reduction in 2012 was due to the cessation of rainfall from the time of pod setting to near to physiological maturity (Figure 2). Moreover, the annual rainfall amount in this season was $866 \mathrm{~mm}$, whereas it was $1067 \mathrm{~mm}$ in the 2014 cropping season. Correlation between yield and annual rainfall for the cropping seasons also showed a strong positive correlation $\left(R^{2}=0.96\right)$, indicating that the yield could be highly affected both by the amount of rainfall and by its distribution. This effect of moisture stress at a critical stage of the soybean crop led to forced maturity and to a significant reduction in its potential yield in accordance with other studies [22]). In the same report, it was shown that a significant lack of water during flowering to pod setting leads to physiological changes in the plant, such as stomatal closure and leaf rolling, and consequently, premature fall of flowers and leaves and pod abortion, which ultimately results in yield reductions [22]. 


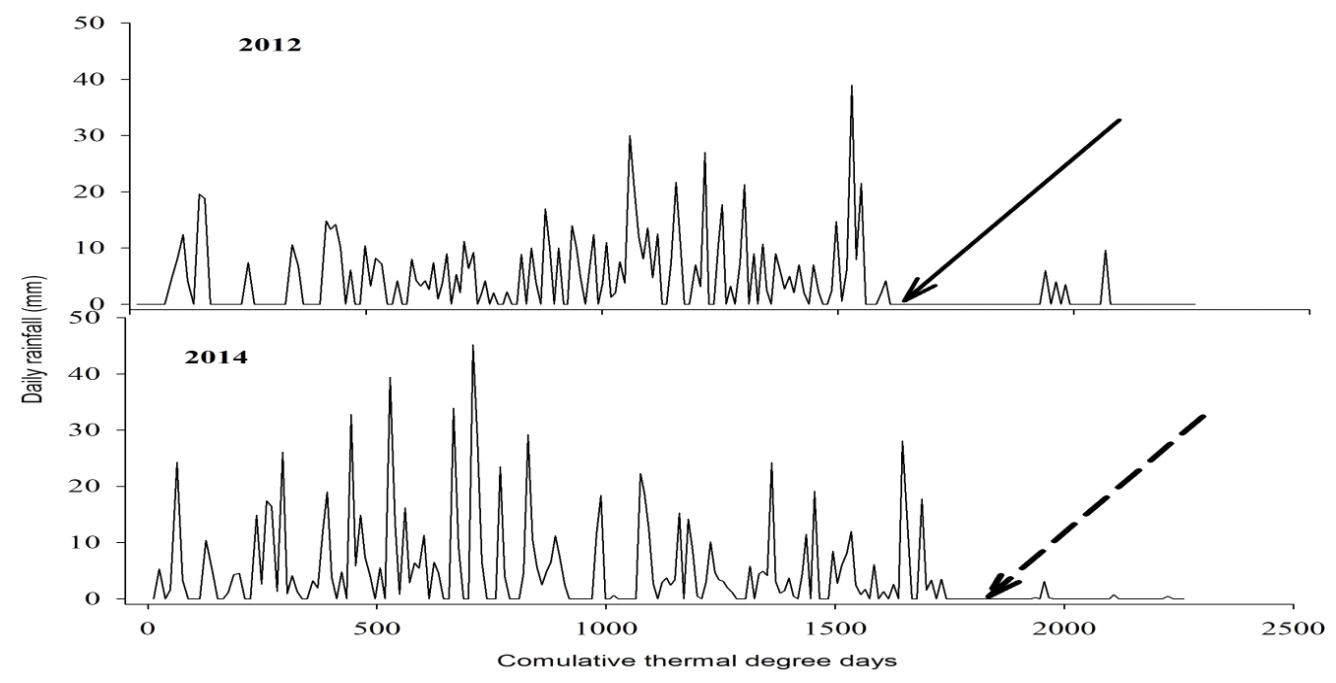

Figure 2. Daily rainfall ( $\mathrm{mm}$ ) versus cumulative thermal degree days (DD) at the Bako Agricultural Research Center, Ethiopia, for the 2012 and 2014 cropping seasons. Note: the solid line indicates cessation of rainfall for 31 days during pod setting (2012), whereas the dashed line (2014) indicates cessation at the time near physiological maturity.

Application of increased rates of farm yard manure considerably enhanced soybean yield in 2012. More than a 8-16\% yield increase was obtained when $9 \mathrm{t} \mathrm{FYM/ha} \mathrm{were} \mathrm{applied} \mathrm{as} \mathrm{compared}$ with the lower application rates ( $3 \mathrm{t} / \mathrm{ha}$ and $6 \mathrm{t} / \mathrm{ha})$. However, there were no significant yield differences observed due to FYM application in 2014. The enhanced crop response to FYM in the 2012 cropping season is attributed to improved soil moisture holding capacity during the short rainy season, in addition to the nutrient supply. Other findings confirm that high manure application rates significantly reduced soil water evaporation as compared to the control treatment and increased soil water storage capacity during the period of pick growth on the maize [23].

In addition, the application of organic manure significantly enhanced soybean yield as compared to the control treatment. Significant yield increases over the control were recorded by $192 \%$ in 2012 and $84 \%$ in 2014 (Figure 3). Corroborating these results, other finding indicated that organic manure supplies nutrients throughout the season for the growth and development of the crop, in addition to improving soil moisture holding capacity and, hence, increased productivity [3].

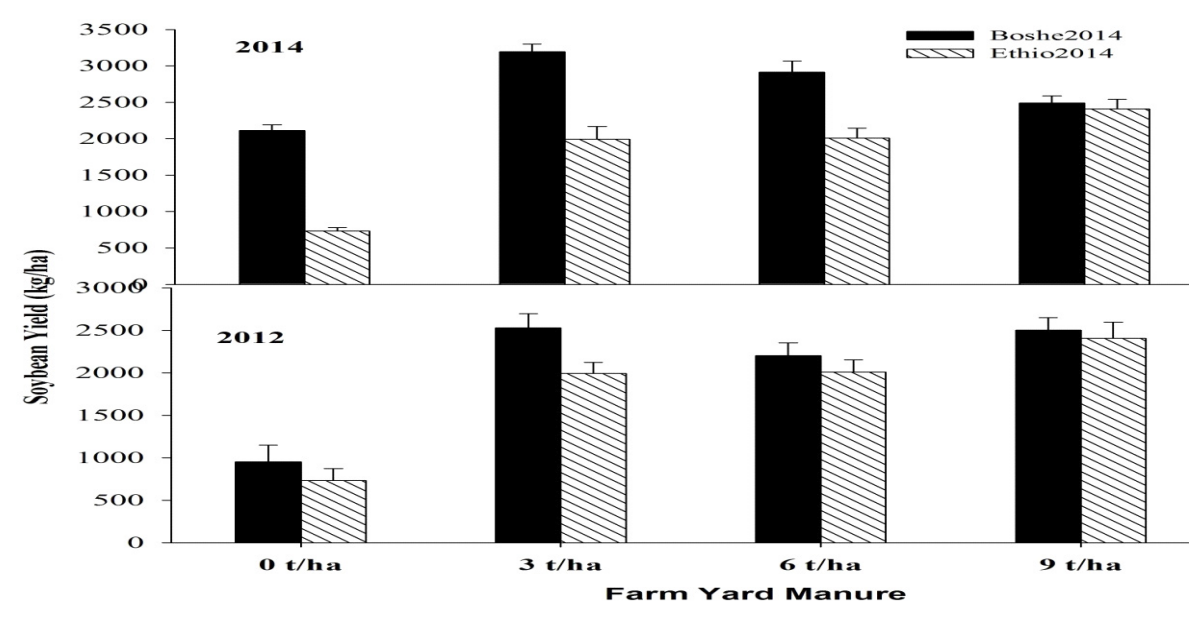

Figure 3. Effect of FYM application rates on yield of soybean varieties in the 2012 and 2014 cropping seasons at Bako, Ethiopia. 
In the 2012 cropping season, the highest significant yield was obtained from the Boshe variety when treated with combined application of $9 \mathrm{t} \mathrm{FYM} \mathrm{/ha} \mathrm{and} 24 \mathrm{~kg} \mathrm{P} /$ ha followed by the treatment combination of $3 \mathrm{t} \mathrm{FYM} / \mathrm{ha}$ and $24 \mathrm{~kg} \mathrm{P} /$ ha (Figure 4). Application of $6 \mathrm{t} \mathrm{FYM/ha} \mathrm{with} 16 \mathrm{~kg} \mathrm{P} / \mathrm{ha}$ also significantly increased grain yield as compared to other treatment means (Figure 4). In general, for the Boshe variety, a 100-200\% yield increase was obtained with a combined application of organic and inorganic fertilizers when compared to the control.

Similarly, Ethio-ugozilavia yields were the greatest with the highest application rates of FYM ( $9 \mathrm{t} / \mathrm{ha})$ and $\mathrm{P}(24 \mathrm{~kg} / \mathrm{ha})$. A linear increase yield was observed when $9 \mathrm{t} \mathrm{FYM} /$ ha were applied with increased rates of $\mathrm{P}$ in 2012 (Figure 4). This result in agreement with another research finding shows that the yield could increase further with the application of higher doses of the organic manure and inorganic fertilizer since it could enhance soil moisture holding capacity in the short rainy season, in addition to soil fertility improvement [24]. In other studies, it was shown that high manure applications significantly reduced soil water evaporation throughout the growing period as compared to the controls and significantly increased soil water storage capacity; hence, it was advised to apply during the dry or short rainy seasons [23].
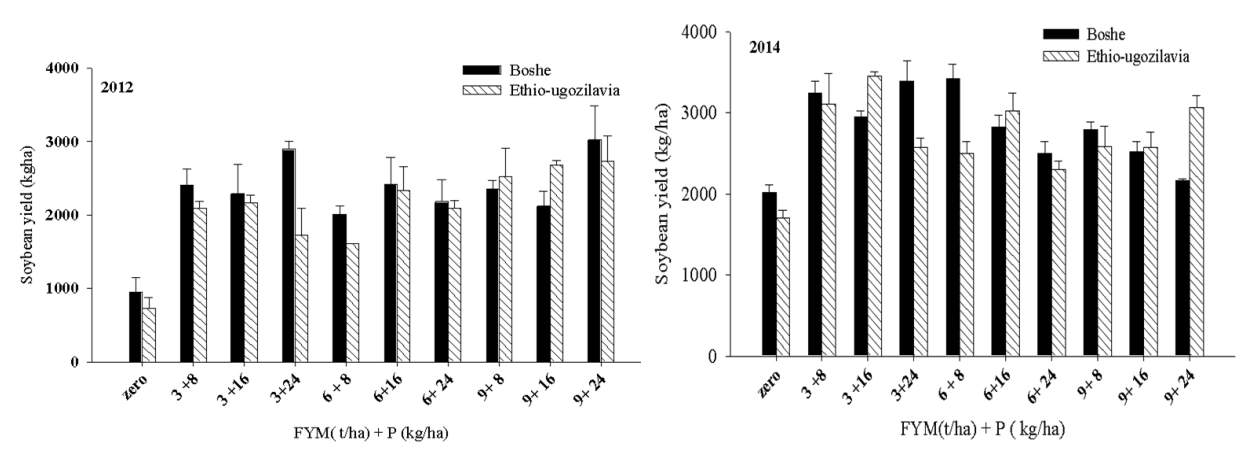

Figure 4. Effect of combined applications of different rates of FYM and phosphorus fertilizer on the yield of soybean varieties in the 2012 (left) and 2014 (right) cropping seasons at Bako, Ethiopia.

In the 2014 cropping season, the response of the soybean varieties to combined applications of organic and inorganic fertilizer were different compared to that of 2012 (Figure 4). The highest significant yield from the Boshe variety was attained at the combined application of $6 \mathrm{t} \mathrm{FYM/ha}$ and $8 \mathrm{~kg} \mathrm{P} /$ ha followed by the combination $3 \mathrm{t} \mathrm{FYM/ha} \mathrm{and} 24 \mathrm{~kg} \mathrm{P} / \mathrm{ha}$. The combination of lower rates of both fertilizer sources ( $3 \mathrm{t} \mathrm{FYM} / \mathrm{ha}$ and $8 \mathrm{~kg} \mathrm{P} / \mathrm{ha}$ ) showed a similar effect on yield performance with that of the highest rates, but resulted in a 53\% yield increase over the control. Likewise, the Ethio-ugozilavia variety showed the highest yield performance when $3 \mathrm{t} \mathrm{FYM/ha} \mathrm{was}$ applied with $16 \mathrm{~kg} \mathrm{P} / \mathrm{ha}$ and $8 \mathrm{~kg} \mathrm{P} / \mathrm{ha}$, which resulted in a respective yield increase of $100 \%$ and $81 \%$ over the control (Figure 4). This result indicate that medium or late maturing types of soybean compete for the resources differently due to the differences in the length of their growing period and other growth characteristics. Ronner et al. [14] also showed that varietal differences in nodulation capacity, root growth and development and the capacity of the nutrient sink resulted in different resource use. The current result also confirmed that with sufficient rain (2014), lower doses of organic fertilizer combined with optimum doses of inorganic fertilizers significantly enhance crop productivity. This might be due to optimum moisture and temperature that might contribute to high decomposition rates of organic manure and in the release of nutrients for the crop. However available phosphorus might not be quite enough for the growth of the crop [25].

\subsection{Soil Fertility Status after Soybean Harvest}

The result of the analysis of variance revealed that soil $\mathrm{pH}$, organic carbon, total nitrogen and available phosphorus were highly $(p<0.01)$ varied across cropping seasons (Table 3). However, 
no significant effects for each observed parameter were recorded with respect to the main effects and their interaction of the three factors. The observed seasonal variation may be due to the history of soil fertility of the experimental sites, which were selected from the different sites at the Bako research site. The result of the initial soil analysis also confirmed that there were considerable variations in soil chemical properties (Table 1). For instance, the total nitrogen of the site was significantly varied and found in the low (2012) and medium (2014) ranges.

Table 3. Combined analysis of variances for $\mathrm{pH}$, organic carbon, total nitrogen and extractable phosphorus after soybean harvest in the 2012 and 2014 cropping seasons at Bako, Western Ethiopia.

\begin{tabular}{|c|c|c|c|c|c|}
\hline \multirow{2}{*}{ Source of Variations } & \multirow{2}{*}{ d.f. } & \multicolumn{4}{|c|}{ Probability Level $(p<0.05)$} \\
\hline & & $\mathrm{pH}\left(\mathrm{H}_{2} \mathrm{O}\right)$ & OC (\%) & TN (\%) & $P(\mathrm{mg} / \mathrm{kg})$ \\
\hline Yr (Year) & 1 & $<0.001$ & $<0.001$ & $<0.001$ & $<0.001$ \\
\hline SBv (Soybean varieties) & 1 & 0.056 & 0.64 & 0.966 & 0.978 \\
\hline Farm Yard Manure (FYM) & 2 & 0.666 & 0.958 & 0.743 & 0.983 \\
\hline $\mathrm{P}$ & 2 & 0.755 & 0.923 & 0.634 & 0.961 \\
\hline $\mathrm{Yr}_{\mathrm{r}} * \mathrm{SBv}$ & 1 & 0.299 & 0.117 & 0.948 & 0.978 \\
\hline $\mathrm{Yr}^{*} \mathrm{FYM}$ & 2 & 0.69 & 0.115 & 0.678 & 0.969 \\
\hline $\mathrm{SBv} * \mathrm{FYM}$ & 2 & 0.997 & 0.334 & 0.186 & 0.628 \\
\hline $\mathrm{Yr} * \mathrm{P}$ & 2 & 0.874 & 0.124 & 0.363 & 0.791 \\
\hline $\mathrm{SBV}^{*} \mathrm{P}$ & 2 & 0.629 & 0.782 & 0.862 & 0.383 \\
\hline FYM $* P$ & 4 & 0.227 & 0.419 & 0.641 & 0.654 \\
\hline $\mathrm{Yr} \times \mathrm{SBV}^{*} \mathrm{FYM}$ & 2 & 0.717 & 0.38 & 0.99 & 0.46 \\
\hline $\mathrm{Yr}^{*} \mathrm{SBV}^{*} \mathrm{P}$ & 2 & 0.71 & 0.279 & 0.856 & 0.148 \\
\hline $\mathrm{Yr}^{*} \mathrm{FYM} * \mathrm{P}$ & 4 & 0.647 & 0.685 & 0.358 & 0.861 \\
\hline $\mathrm{SBV}^{*} \mathrm{FYM}{ }^{*} \mathrm{P}$ & 4 & 0.543 & 0.361 & 0.42 & 0.563 \\
\hline $\mathrm{Yr} * \mathrm{SBv}^{*} \mathrm{FYM}^{*} \mathrm{P}$ & 4 & 0.592 & 0.024 & 0.669 & 0.23 \\
\hline Blocks & 2 & 0.038 & 0.028 & 0.072 & 0.037 \\
\hline Residual & 70 & - & - & - & - \\
\hline Total & 107 & - & - & - & - \\
\hline
\end{tabular}

In the 2012 cropping season, soil $\mathrm{pH}$ after soybean harvest ranged from 5.2-5.7, which was moderate to strongly acidic (Table 4). Application of FYM did not significantly affect the soil $\mathrm{pH}$ though there is a slight increase when compared to the control plot. This might be due to buffering capacity of the organic matter by releasing some organic compounds that fix $\mathrm{H}^{+}, \mathrm{AL}^{+3}$ and other cations [25]. Soils with a high amount of organic matter due to the addition of organic materials have high cation exchange capacity (CEC) and buffering capacities to stabilize soil $\mathrm{pH}$ [10]. Organic carbon and nitrogen content also showed little variation due to treatment applications (Table 4), but as per the classification, these values are found under moderate ranges [26] Since rainfall amount and distribution over the season (2012) were unexpectedly very low, decomposition rates of applied organic manure and soybean litter fall might be considerably affected, and hence, the buildup of soil organic matter may have temporarily been decreased $[25,27]$.

On the other hand, there were slight improvements of the organic carbon content due to the precursor crop and combined application of the fertilizers. For instance, the early type of soybean precursor with combined application of $9 \mathrm{t} \mathrm{FYM/ha} \mathrm{and} 16 \mathrm{~kg} \mathrm{P} /$ ha increased the organic carbon content of the soil by $16 \%$ compared to the result obtained before planting (Table 1). The available phosphorus was also found in the low range, which could be due to the lower soil organic matter status and available phosphorus of the experimental soils, which were dominated by the $\mathrm{HPO}_{4}{ }^{2-}$ anion found in strongly acidic soils $[10,27]$. 
Table 4. Effects of soybean varieties, FYM and inorganic P fertilizer application on soil $\mathrm{pH}$, organic carbon, total nitrogen and available phosphorus after soybean harvesting in the 2012 cropping season at Bako, Western Ethiopia.

\begin{tabular}{|c|c|c|c|c|c|c|c|c|c|}
\hline \multicolumn{2}{|c|}{ Fertilizer } & \multicolumn{2}{|c|}{$\mathrm{pH}\left(\mathrm{H}_{2} \mathrm{O}\right)$} & \multicolumn{2}{|c|}{ TN (\%) } & \multicolumn{2}{|c|}{ OC (\%) } & \multicolumn{2}{|c|}{$P(\mathrm{mg} / \mathrm{kg})$} \\
\hline FYM (t/ha) & P (kg/ha) & Boshe & Ethio & Boshe & Ethio & Boshe & Ethio & Boshe & Ethio \\
\hline 0 & 0 & 5.36 & 5.29 & 0.14 & 0.12 & 1.81 & 1.61 & 5.90 & 5.80 \\
\hline 3 & 8 & 5.36 & 5.70 & 0.15 & 0.13 & 1.90 & 1.71 & 7.08 & 6.64 \\
\hline 3 & 16 & 5.76 & 5.47 & 0.21 & 0.12 & 1.83 & 1.44 & 6.64 & 6.03 \\
\hline 3 & 24 & 5.36 & 5.31 & 0.16 & 0.13 & 1.98 & 1.44 & 6.05 & 6.60 \\
\hline 6 & 8 & 5.56 & 5.42 & 0.12 & 0.11 & 1.64 & 1.67 & 6.07 & 5.33 \\
\hline 6 & 16 & 5.41 & 5.48 & 0.11 & 0.14 & 1.78 & 1.58 & 5.61 & 7.08 \\
\hline 6 & 24 & 5.38 & 5.57 & 0.17 & 0.12 & 1.80 & 1.51 & 8.56 & 6.01 \\
\hline 9 & 8 & 5.38 & 5.57 & 0.12 & 0.14 & 1.87 & 1.39 & 6.15 & 6.98 \\
\hline 9 & 16 & 5.25 & 5.24 & 0.12 & 0.13 & 1.92 & 1.43 & 6.05 & 6.47 \\
\hline 9 & 24 & 5.49 & 5.58 & 0.12 & 0.15 & 1.78 & 1.78 & 6.18 & 7.46 \\
\hline Mean & & 5.43 & 5.46 & 0.13 & 0.13 & 1.71 & 1.56 & 6.43 & 6.44 \\
\hline LSD & & \multicolumn{2}{|c|}{ NS } & \multicolumn{2}{|c|}{ NS } & \multicolumn{2}{|c|}{ NS } & \multicolumn{2}{|c|}{ NS } \\
\hline $\mathrm{CV}$ & & \multicolumn{2}{|c|}{6} & \multicolumn{2}{|c|}{18} & \multicolumn{2}{|c|}{25} & \multicolumn{2}{|c|}{19} \\
\hline
\end{tabular}

In the 2014 cropping season, however, the soil chemical properties of the experimental site after soybean harvesting were completely different as compared with 2012 due to differences in the rainfall amount and distribution that might have affected organic matter decomposition. Soil $\mathrm{pH}$ ranged from 4.4-4.6, which is strongly acidic (Table 5). Organic carbon content of the soil was slightly improved due to the application of organic manure as compared to the control $[27,28]$. For instance, application of $9 \mathrm{t}$ FYM/ha with various rates of phosphorus resulted in organic carbon content ranging from $2.7-3.1 \%$, which was increased by $5-19 \%$ over the control plot, respectively. Growing of soybean even without fertilizer application improved organic carbon of the soil by 13\% compared with the value observed prior to planting (Tables 1 and 5). This improvement of soil fertility might be due to a suitable soil environment, such as optimum moisture and temperature, which determine the rate of organic manure decomposition and soybean litter fall and nutrient release from crop residues [29-31]. For instance, organic carbon of the soil after soybean harvest in 2012 was $1.63 \%$, whereas it was $2.60 \%$ in 2014, showing a direct correlation with annual rainfall (Tables 1 and 5). Similarly, total nitrogen content of the soil varied from $2.26-2.29 \%$, which is categorized in the high range.

Table 5. The effects of soybean varieties, farmyard manure and inorganic fertilizer application on soil $\mathrm{pH}$, organic carbon, total nitrogen contents and available phosphorus after soybean harvesting in 2014 at Bako, Western Ethiopia.

\begin{tabular}{|c|c|c|c|c|c|c|c|c|c|}
\hline \multicolumn{2}{|c|}{ Fertilizer } & \multicolumn{2}{|c|}{$\mathrm{pH}\left(\mathrm{H}_{2} \mathrm{O}\right)$} & \multicolumn{2}{|c|}{ Total N (\%) } & \multicolumn{2}{|c|}{ OC (\%) } & \multicolumn{2}{|c|}{ P (mg/kg) } \\
\hline FYM (t/ha) & P (kg/ha) & Boshe & Ethio & Boshe & Ethio & Boshe & Ethio & Boshe & Ethio \\
\hline 0 & 0 & 4.55 & 4.50 & 0.31 & 0.26 & 2.55 & 2.54 & 15.33 & 17.00 \\
\hline 3 & 8 & 4.47 & 4.68 & 0.27 & 0.27 & 2.48 & 2.62 & 15.67 & 17.33 \\
\hline 3 & 16 & 4.44 & 4.70 & 0.29 & 0.27 & 2.57 & 2.35 & 18.33 & 15.67 \\
\hline 3 & 24 & 4.49 & 4.59 & 0.29 & 0.29 & 2.59 & 2.51 & 14.67 & 19.33 \\
\hline 6 & 8 & 4.42 & 4.56 & 0.28 & 0.28 & 2.24 & 2.66 & 16.67 & 16.00 \\
\hline 6 & 16 & 4.35 & 4.57 & 0.27 & 0.26 & 2.40 & 2.86 & 19.33 & 15.67 \\
\hline 6 & 24 & 4.46 & 4.57 & 0.28 & 0.25 & 2.63 & 2.90 & 16.00 & 18.67 \\
\hline 9 & 8 & 4.46 & 4.63 & 0.29 & 0.29 & 2.67 & 2.83 & 18.33 & 17.67 \\
\hline 9 & 16 & 4.52 & 4.47 & 0.27 & 0.27 & 2.72 & 2.73 & 16.67 & 17.00 \\
\hline 9 & 24 & 4.52 & 4.65 & 0.25 & 0.29 & 3.02 & 2.96 & 17.00 & 15.33 \\
\hline LSD & & \multicolumn{2}{|c|}{ NS } & \multicolumn{2}{|c|}{ NS } & \multicolumn{2}{|c|}{ NS } & \multicolumn{2}{|c|}{ NS } \\
\hline $\mathrm{CV}$ & & \multicolumn{2}{|c|}{3} & \multicolumn{2}{|c|}{11} & \multicolumn{2}{|c|}{13} & \multicolumn{2}{|c|}{17} \\
\hline
\end{tabular}

\subsection{Finger Millet Performance due to Residual Effects}

The yields of finger millet as influenced by the residual effects of the precursor soybean crop showed highly significant $(p<0.01)$ differences due to seasonal variations, FYM and the interactions 
among varieties and chemical fertilizer rates (Table 6). There was also a three-way interaction, though not strongly significant. Even though seasonal variations might influence the yield of finger millet, variations in land history of the experimental site (Table 1) and soil fertility status after combined application of the fertilizers to soybean in 2012 (Table 3) and 2014 (Table 4) might have contributed to significant differences in the yield performance of the subsequent finger millet.

Table 6. Analysis of variance for yield performance of subsequent finger millet (in the 2013 and 2015 cropping seasons) as influenced by the residual effects of soybean precursors and the application of FYM and chemical P fertilizer at Bako, Western Ethiopia.

\begin{tabular}{|c|c|c|c|c|}
\hline Source of Variation & d.f. & Mean Square & Variance & $F$ pr. \\
\hline $\mathrm{Yr}$ & 1 & $4,955,298$ & 67.31 & $<0.001$ \\
\hline Var & 1 & 186,757 & 2.54 & 0.116 \\
\hline FYM & 2 & 651,771 & 8.85 & $<0.001$ \\
\hline $\mathrm{P}$ & 2 & 11,496 & 0.16 & 0.856 \\
\hline $\mathrm{Yr} * \operatorname{Var}$ & 1 & 184,306 & 2.5 & 0.118 \\
\hline $\mathrm{Yr}^{*} \mathrm{FYM}$ & 2 & 505,342 & 6.86 & 0.002 \\
\hline Var ${ }^{*}$ FYM & 2 & 222,399 & 3.02 & 0.055 \\
\hline $\mathrm{Yr} * \mathrm{P}$ & 2 & 47,602 & 0.65 & 0.527 \\
\hline Var $* P$ & 2 & 885,629 & 12.03 & $<0.001$ \\
\hline FYM $* P$ & 4 & 645,157 & 8.76 & $<0.001$ \\
\hline $\mathrm{Yr} * \operatorname{Var}{ }^{*} \mathrm{FYM}$ & 2 & 497,600 & 6.76 & 0.002 \\
\hline $\mathrm{Yr} * \operatorname{Var}^{*} \mathrm{P}$ & 2 & 883,920 & 12.01 & $<0.001$ \\
\hline $\mathrm{Yr}^{*} \mathrm{FYM} * \mathrm{P}$ & 4 & 215,078 & 2.92 & 0.027 \\
\hline Var ${ }^{*} \mathrm{FYM} * \mathrm{P}$ & 4 & 189,943 & 2.58 & 0.055 \\
\hline $\mathrm{Yr}^{*} \mathrm{Var}^{*} \mathrm{FYM}{ }^{*} \mathrm{P}$ & 4 & 237,412 & 3.23 & 0.057 \\
\hline Block & 2 & 172,635 & 2.35 & 0.103 \\
\hline Residual & 70 & 73,614 & & \\
\hline Total & 107 & & & \\
\hline
\end{tabular}

In the 2013 cropping season, the significantly higher yield of finger millet was obtained when sown on a previous (2012) soybean plot that received $3 \mathrm{t} \mathrm{FYM/ha}$ as a main effect followed by $6 \mathrm{t} \mathrm{FYM/ha} \mathrm{(Figure} \mathrm{5).} \mathrm{This} \mathrm{might} \mathrm{be} \mathrm{due} \mathrm{to} \mathrm{gradual} \mathrm{decomposition} \mathrm{of} \mathrm{organic} \mathrm{manure} \mathrm{that} \mathrm{slowly}$ releases nutrients for subsequent crops [3,32]. However, high doses of organic fertilizer application in the short rainy season might take more time to be decomposed and converted to soil organic matter. This could be due to the limited population of decomposing micro-organisms and their nutrients, particularly nitrogen, and other soil environmental factors that may hamper rapid decomposition of the manure. However, in the long run, higher doses of the manure may provide adequate nutrients for the following crop rotation $[30,33]$. Interestingly, the precursor soybean crop without fertilizer application significantly increased the yield of the subsequent finger millet, which is statistically on par with yields obtained from the mono-cropping practice (farmers' practice with no rotation) that received recommended fertilizer applications $(20 \mathrm{~kg} \mathrm{P} / \mathrm{ha})$. This may indicate that soybean litter fall has the potential to rapidly decompose and increase soil organic matter, while it can also enhance the availability of nitrogen and other nutrients [34,35].

Evidently, finger millet yield showed respective yield increments of $6 \%$ and $22 \%$ when planted following soybean precursor with $3 \mathrm{t} \mathrm{FYM/ha}$ and $6 \mathrm{t}$ FYM/ha compared with farmers' practice, and similar results were also reported by Hemalatha and Chellamuthu [30].

In the 2015 cropping season, however, the yield performance of finger millet was significantly higher by $20 \%$ as compared with the yield obtained in 2013 (Figure 5). This might be attributed to variations in soil fertility status after soybean harvest, though the rainfall amount and distribution during the growing of the two seasons were almost similar. In other words, the residual effects of soybean precursor (that produced higher biomass and dropped as litterfall, which may enhance the soil fertility) and fertilizer applied in 2014 considerable enhanced the yield of the following finger millet obtained in 2015 compared to 2013. The residual effect of the different rates of FYM on the 
following finger millet yield did not show significant difference among the means, though there were slight yield increases when compared with the treatments of farmers' practices and soybean precursor receiving no fertilizer (Figure 5). These results indicate that $100 \%$ of the chemical fertilizer cost could be saved when finger millet is rotated with soybean precursor crops with the application of organic manure, which is in agreement with a previous finding [24].

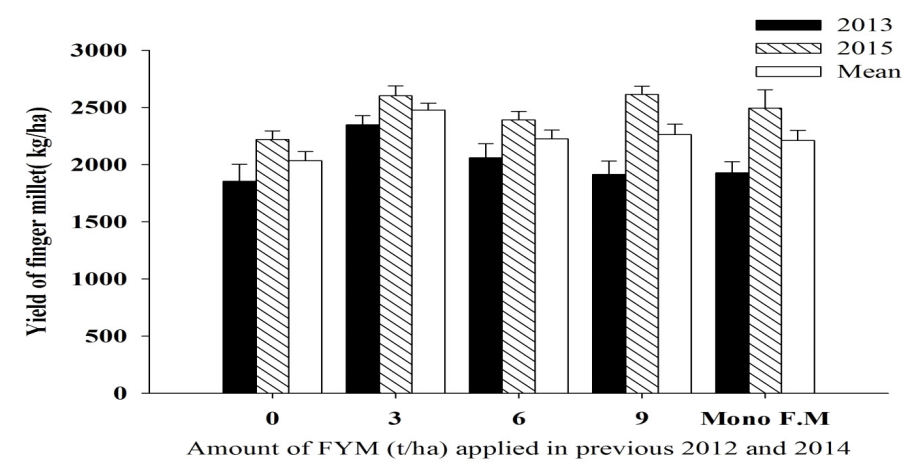

Figure 5. Residual effect of farmyard manure applied to the precursor soybean as the main effect on the yield of subsequent finger millet at Bako, Western Ethiopia. Mono F.M = farmers' practice, continuous mono-cropping of finger millet with recommended DAP fertilizer.

The interaction effect of organic manure with chemical $\mathrm{P}$ fertilizer applied to the soybean crop significantly affected the performance of the subsequent finger millet (Figure 6). In 2013, the significantly variable response of finger millet was observed due to the residual effects of organic manure combined with inorganic $P$ fertilizer [6]. The highest finger millet yield was obtained when planted on the plot from which soybean that received $6 \mathrm{t} \mathrm{FYM/ha} \mathrm{in} \mathrm{combination} \mathrm{with} 8$ and $16 \mathrm{~kg}$ $\mathrm{P} /$ ha was harvested. In this case, yield increase over the farmers' practices was up to $30 \%$. Moreover, the effect of the soybean precursor even without fertilizer use considerably increased the yield of the following finger millet, which is statistically on par with the yield obtained from the farmers' practice.

In the 2015 cropping season, the highest yield of finger millet $(2825 \mathrm{~kg} / \mathrm{ha})$ was obtained when planted on soybean precursor plots that received $3 \mathrm{t} \mathrm{FYM/ha} \mathrm{with} 24 \mathrm{~kg} \mathrm{P} / \mathrm{ha}$ followed by $9 \mathrm{t} \mathrm{FYM} / \mathrm{ha}$ with $8 \mathrm{~kg} \mathrm{P} /$ ha, which are statistically on par (Figure 6). Similar to the result of 2013, the yield of finger millet was at statistical parity when planted following soybean precursor without fertilizer use as compared with farmers' practice, and a similar result was also reported by Bado et al. [15].

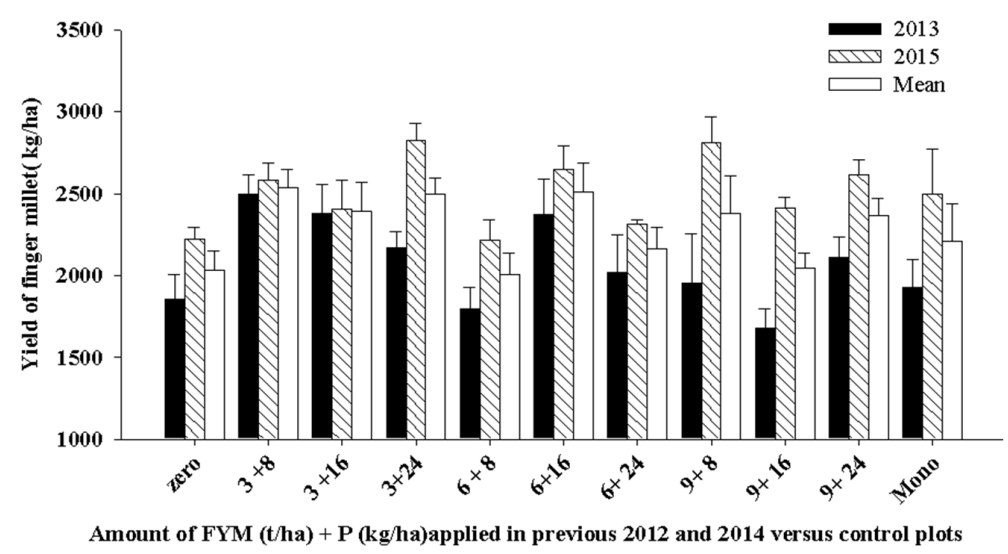

Figure 6. Residual effect of FYM combined with chemical $P$ fertilizer applied to soybean precursor on the yield of subsequent finger millet at Bako, Western Ethiopia. Mono F.M = farmers' practice, continuous mono-cropping of finger millet with recommended use of DAP fertilizer. 
The interaction of residual effects of soybean varieties, due to nitrogen fixation and crop litterfall, and the application of FYM significantly influenced the yield of the succeeding finger millet (Figure 7). In 2013, the highest yield of finger millet was obtained when planted on the plot of the precursor Boshe variety, which received $3 \mathrm{t} \mathrm{FYM/ha.} \mathrm{This} \mathrm{result} \mathrm{indicates} \mathrm{that} \mathrm{during} \mathrm{the} \mathrm{short} \mathrm{rainy} \mathrm{season,} \mathrm{the} \mathrm{early}$ maturing soybean type produces biomass that contributes to soil organic matter through litter fall drops (2012) and hence to soil fertility improvement [12]). Moreover, this result is in line with other research findings indicated that the lower rates of applied FYM also more easily decompose during the short rainy seasons and release some nutrients for the next crops as compared with the higher doses [11].

In 2015, however, the late type of precursor soybean (Ethio-ugozilavia) with the application of higher doses of 6 and $9 \mathrm{t} \mathrm{FYM/ha} \mathrm{resulted} \mathrm{in} \mathrm{a} \mathrm{significantly} \mathrm{increased} \mathrm{yield} \mathrm{of} \mathrm{the} \mathrm{subsequent}$ crop as compared with yield obtained in the 2013 (Figure 7) with a 22\% and 18\% yield increase, respectively [36]. These results revealed that with a good rainy season and under optimum soil conditions, a late type of soybean precursor crop may produce more biomass, and hence, higher litter fall would be dropped and decomposed in the soil.

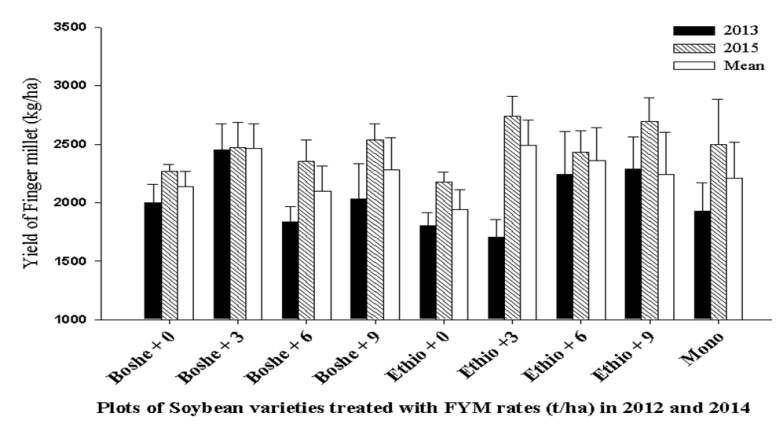

Figure 7. Residual effects of precursor soybean crop and applied FYM on the yield of the subsequent finger millet crop at Bako, Western Ethiopia. Mono F.M = farmers' practice, continuous mono-cropping of finger millet with the recommended use of DAP fertilizer.

Moreover, the higher doses of organic manure might be more easily decomposed due to adequate soil moisture during good rainy seasons. Other soil environmental factors such as the soil N:C ratio might also contribute to higher microbial populations that decompose the organic manure more rapidly [1], increasing the nutrient availability for the next crop in the rotation (Table 4 and Figure 7). However, planting of finger millet following a soybean precursor crop that received the $3 \mathrm{t} \mathrm{FYM} / \mathrm{ha}$ resulted in comparable yield to those obtained by the following farmers' practices. Thus, the alternative use of FYM could save $100 \%$ of the cost of chemical fertilizer inputs and hence can be recommended especially for poor farmers that have access to the sufficient amounts of FYM. On the other hand, the use of a late type soybean precursor crop even without fertilizer application resulted in a greater than $29 \%$ yield increase of the subsequent finger millet crop when grown under moderate soil fertility and adequate annual rainfall conditions (2014) as compared to a combined short rainy season (2012) and a low soil fertility status.

\section{Conclusions}

Low soil fertility is one of the main challenges to produce surplus food for an ever-increasing population, particularly in the Ethiopian context. Continuous mono-cropping with one or two chemical fertilizer sources is one of the main causes of the gradual soil fertility depletion. However, crop rotations with the integrated use of fertilizer sources could help to avert such problems and lead to soil fertility improvement. Moreover, this can increase the production and productivity of rotationally-grown crops and hence address the food security problem. 
The rainfall amount and distribution significantly affected the response of soybean to fertilizers inputs. In 2012, a year with a short rainy season, there was a differential variety response to the integrated fertilizer applications. Even though the application of $9 \mathrm{t} \mathrm{FYM} / \mathrm{ha}$ with $24 \mathrm{~kg} \mathrm{P} / \mathrm{ha}$ to the Boshe variety provided the highest yield, the use of $3 \mathrm{t} \mathrm{FYM/ha} \mathrm{with} 24 \mathrm{~kg} \mathrm{P} /$ ha gave comparable yields. On the other hand, the yield of the Ethio-ugozilavia variety was significantly increased with the application of $9 \mathrm{t}$ FYM/ha and increased rates of chemical P fertilizer rates. In 2014, a year with a long rainy season, however, lower rates of both fertilizer sources ( $3 \mathrm{t} \mathrm{FYM/ha} \mathrm{and} 8 \mathrm{~kg} \mathrm{P} / \mathrm{ha}$ ) showed similar yields for the Boshe variety as compared with the highest rates of combined fertilizers applied. The Ethio-ugozilavia variety showed the maximum yields when $3 \mathrm{t} \mathrm{FYM/ha} \mathrm{were} \mathrm{applied}$ with $16 \mathrm{~kg}$ P/ha followed by $3 \mathrm{t}$ FYM with $8 \mathrm{~kg} \mathrm{P} / \mathrm{ha}$, resulting in significant yield increases of $64 \%$ and $45 \%$, respectively.

The initial soil fertility status in terms of organic carbon, total nitrogen and available phosphorus was considerably lower in 2012 than in 2014, but the soil pH was higher in 2012. Similarly, the soil fertility status after soybean harvest was lower in 2012. However, a slight improvement in the organic carbon and total nitrogen contents, particularly in 2014, was observed due to the effect of the precursor crop and the combined use of the organic and inorganic fertilizers.

The residual effect of $3 \mathrm{t}$ FYM/ha resulted in a significantly higher grain yield of finger millet in 2013. However, higher doses of organic amendments did not significantly increase yields in the same season. On the other hand, in 2015, the residual effect of FYM application resulted in a slight yield increase of the subsequent finger millet crop. Furthermore, a late type precursor soybean variety with an application of higher doses of FYM ( 6 and $9 \mathrm{t} \mathrm{FYM/ha)} \mathrm{significantly} \mathrm{increased} \mathrm{the} \mathrm{yield} \mathrm{of}$ the subsequent finger millet crop. Interestingly, the precursor soybean without fertilizer application significantly increased the yield of subsequent finger millet. The results showed that the yield of finger millet increased by $6 \%$ and $22 \%$ when planted following a soybean precursor crop with $3 \mathrm{t} \mathrm{FYM} / \mathrm{ha}$ and $6 \mathrm{t}$ FYM/ha compared to the farmers' practice.

In conclusion, the use of early types of soybean with the application of lower rates organic ( $3 \mathrm{t} \mathrm{FYM/ha)} \mathrm{and} \mathrm{higher} \mathrm{inorganic} \mathrm{fertilizers} \mathrm{(} 24 \mathrm{~kg} \mathrm{P} / \mathrm{ha}$ ) resulted in increased yields during a short rainy season (2012) as compared to the planting of a late-soybean variety. Hence, we recommend this option to be used whenever a rainfall shortage is expected and/or in semi-arid areas where moisture is a limiting factor. On the other hand, if the rainfall amount and distribution are optimum, as observed in the 2014, a late maturing of soybean variety receiving $6 \mathrm{t} \mathrm{FYM/ha} \mathrm{and} \mathrm{8-16} \mathrm{P} \mathrm{kg/ha} \mathrm{could} \mathrm{give}$ significantly better yields as compared to early types. Regarding the finger millet response to residual nutrient effects of the soybean precursor crop with a combined fertilizer application, use of an early type of soybean variety with $3 \mathrm{t} \mathrm{FYM/ha} \mathrm{in} \mathrm{a} \mathrm{short} \mathrm{rainy} \mathrm{season} \mathrm{could} \mathrm{potentially} \mathrm{increase} \mathrm{the} \mathrm{yields}$ of a subsequent finger millet crop. However, the application of the higher rates of organic manure (6-9 t FYM/ha) to a late type variety of the precursor crop in good rainy seasons could potentially enhance the yield of the subsequent millet crop. Moreover, planting of finger millet following a late type soybean precursor crop that received $3 \mathrm{t} F Y M /$ ha resulted in comparable yields compared to farmers' practices, which could save $70-85 \%$ of the cost of chemical fertilizer inputs. Hence, this option can be recommended for poor farmers with limited capacity to afford the cost of the chemical fertilizers that have access to sufficient amounts of organic manure.

Acknowledgments: The authors greatly thank the Oromia Agricultural Research Institute for financial support for the execution of the experiment. The authors also sincerely acknowledge Bako Agricultural Research Center for technical and managerial support during the experimental periods. Great thanks also go to the pulses and oil research teams of the Center and to Bayisa Baye who thoroughly supervised and collected data regularly.

Author Contributions: Abebe Zerihun conceived of, designed and performed the experiments. Abebe Zerihun and Deressa Haile analyzed the data and wrote the paper.

Conflicts of Interest: The authors declare no conflict of interest. 


\section{References}

1. Smaling Eric, M.A.; Stephen, M.; Nandwa, B.H.J. Replenishing Soil Fertility in Africa. In Proceedings of the an International Symposium, Madison, WI, USA, 5-8 August 1997; Marian, K., Hatfield, V.J., Bigham, J.M., Eds.; Soil Science Society of America: Madison, WI, USA; pp. 46-61.

2. Tolera, A.; Feyisa, D.; Friesen, D.K.; Agricultural, B.; Coordinator, R. Effects of Crop Rotation and N-P Fertilizer Rate on Grain Yield and Related Characteristics of Maize and Soil Fertility at Bako, Western Oromia, Ethiopia. East Afr. J. Sci. 2009, 3, 70-79.

3. Zerihun, A.; Sharma, J.J.; Nigussie, D.; Fred, K. The effect of integrated organic and inorganic fertilizer rates on performances of soybean and maize component crops of a soybean/maize mixture at Bako, Western Ethiopia. Afr. J. Agric. Res. 2013, 8, 3921-3929.

4. Kombiok, J.M.; Buah, S.S.J.; Segbedji, J.M. Enhancing Soil Fertility for Cereal Crop Production through Biological Practices and the Integration of Organic and In-Organic Fertilizers in Northern Savanna Zone of Ghana. Soil Fertil. 2008. [CrossRef]

5. Shiningayamwe, E.N. Crop Rotation as a Soil Fertility Improvement Strategy Using Different Legumes on a Pearl Millet Yield; Agricola: Tsumbeb, Namibia, 2012.

6. Varalakshmi, L.R.; Srinivasamurth, C.A.; Bhaskar, S. Effect of Integared Use of Organic Manure and Inorganic Fertilizer on Organic Carbon, Available NP and K in Sustaining Productivity of Ground-Finger Millet Cropping System. Sustain. Agric. Green Manure Crops 2005, 53, 315-318.

7. Yusuf, A.A.; Iwuafor, E.N.O.; Abaidoo, R.C.; Olufajo, O.O.; Sanginga, N. Effect of Crop Rotation and Nitrogen Fertilization on Yield and Nitrogen Efficiency in Maize in the Northern Guinea Savanna of Nigeria. Afr. J. Agric. Res. 2009, 4, 913-921.

8. Kiari, S.A. Improving Millet-Cowpea Productivity and Soil Fertility with Crop Rotation, Row Arrangement and Cowpea Density in American-Eurasian. J. Agric. Environ. Sci. 2014, 14, 110-115.

9. Zerihun, A.; Abera, T.; Dedefo, T.; Fred, K. Maize yield response to crop rotation, farmyard manure and inorganic fertilizer application in Western Ethiopia. Afr. J. Agric. Res. 2013, 8, 5889-5895.

10. Abera, T.; Semu, E.; Debele, T.; Wegary, D.; Kim, H. Nutrient Status of Soils from Farmers' Maize Fields in Mid Altitude Areas of Western Ethiopia. Merit Res. J. Agric. Sci. Soil Sci. 2015, 3, 113-121.

11. Schroth, G.; Ehmann, J.L.; Arrios, E.B. Soil Nutrient Availability and Acidity; CAB International: Accra, Ghana, 2003.

12. Grassini, P.; Torrion, J.A.; Cassman, K.G.; Yang, H.S.; Specht, J.E. Drivers of spatial and temporal variation in soybean yield and irrigation requirements in the western US Corn Belt. Field Crops Res. 2014, 163, 32-46. [CrossRef]

13. Zerihun, A.; Alemayo, D.; Wolde-Meskel, E. On Farm Yield Responses of Soybean (Glycine Max L. (Merrill)) to Fertilizer Sources Under Different Soil Acidity Status in Gabu Sayo district, Western Ethiopia. J. Agron. 2015, 14, 30-36.

14. Ronner, E.; Franke, A.C.; Vanlauwe, B.; Dianda, M.; Edeh, E.; Ukem, B.; Bala, A.; van Heerwaarden, J.; Giller, K.E. Field Crops Research Understanding Variability in Soybean Yield and Response to P-Fertilizer and Rhizobium Inoculants on Farmers' Fields in Northern Nigeria. Field Crops Res. 2016, 186, $133-145$. [CrossRef]

15. Bado, V.B.; Cescas, M.P.; Bationo, A.; Sedogo, M.P.; Cescas, M.P.; Traore, T. Influence of Legumes on Nitrogen (N) Fertilizer Recommendations for Succeeding Sorghum in the Guinea Savannah of West Africa. Afr. J. Agric. Res. 2013, 8, 6416-6421.

16. Ministry of Agriculture and Rural Development (MARD). Crop Variety Registration Issue No.16; Ministry of Agriculture and Rural Development, Crop Development Department: Addis Ababa, Ethiopia, 2013.

17. Kamara, A.Y.; Kwari, J.; Ekeleme, F.; Omoigui, L.; Abaidoo, R. Effect of Phosphorus Application and Soybean Cultivar on Grain and Dry Matter Yield of Subsequent Maize in the Tropical Savannas of North-Eastern Nigeria. Afr. J. Biotechnol. 2008, 7, 2593-2599.

18. Schelze, J.; Temple, G.; Temple, S.J.; Beschow, H.; Vance, C.P. Nitrogen Fixation by White Lupin under Phosphorus Deficiency Nitrogen Fixation by White Lupin under Phosphorus Deficiency. Ann. Bot. 2006, 98, 731-740. [CrossRef] [PubMed]

19. Walkley, A.; Black, C.A. An examination of Degtjareff method for determining soil organic matter and the proposed modification of the chromic acid titration method. Soil Sci. 1934, 37, 29-38. [CrossRef] 
20. Bray, H.R.; Kurtz, L.T. Determination of organic and available forms of phosphorus in soils. Soil Sci. 1945, 59, 39-46. [CrossRef]

21. Motsara, M.L.; Roy, R.N. Guide to Laboratory Establishment for Plant and Nutrients Analysis; FAO Fertilizer and Plant Nutrition Bulletin 19; Food and Agriculture Organization of the United Nations: New Delhi, India, 2008.

22. Vinicius, C. Rainfall Variability and Soybean Yield in Paraná State, Southern Brazil. Int. J. Environ. Agric. Res. 2016, 2, 86-97.

23. Wang, X.J.; Jia, Z.K.; Liang, L.Y.; Kang, S.Z. Effect of Manure Management on the Temporal Variations of Dryland Soil Moisture and Water Use Efficiency of Maize. J. Agric. Sci. Technol. 2013, 15, 1293-1304.

24. Abebe, Z.; Tadesse, S.; Tola, M. Multiple Advantages of Pigeon Pea (Cajanas Cajan) in Maize Based Cropping Systems: Used as Live Stake for Climbing Bean with Multiple Advantages of Pigeon Pea (Cajanas Cajan) in Maize Based Cropping Systems: Used as Live Stake for Climbing Bean. J. Nat. Sci. Res. 2016, 6, 58-69.

25. Palm, C.A.; Myers, R.J.; Nandwa, S. Combined Use of Organic and Inorganic Nutrient Sources for Soil Fertility Maintenance and Replenishment. In Replenishing Soil Fertility in Africa; Soil Science Society of America: Madison, WI, USA.

26. Pam, H.; Brian, M. Interpreting Soil Test Results What Do All The Numbers Mean? CSIRO Publishing: Collingwood, Australia, 2007.

27. Achalu, C.; Gebrekidan, H.; Kibret, K.; Tadesse, A. Status of Selected Physicochemical Properties of Soils under Different Land Use Systems of Western Oromia, Ethiopia. J. Biol. Environ. Sci. 2012, 2, 57-71.

28. Ghosh, P.K.; Bandyopadhyay, K.K.; Manna, M.C.; Mandal, K.G.; Misra, A.K.; Hati, K.M. Comparative Effectiveness of Cattle Manure, Poultry Manure, Phosphocompost, and Fertilizer-NPK on Three Cropping Systems in Vertisols of Semi-Arid Tropics. II. Dry Matter Yield, Nodulation, Chlorophyll Content and Enzyme Activity. Biol. Resour. Technol. 2004, 95, 85-93. [CrossRef] [PubMed]

29. Valenzuela, H.; Smith, J. Pigeonpea; Utah State University Publisher: Boulder, CO, USA, 2002.

30. Hemalatha, S.; Chellamuthu, S. Impacts of Long-Term Fertilization on Soil Nutritional Quality under Finger Millet: Maize Cropping Sequence. J. Environ. Res. Dev. 2013, 7, 1571-1576.

31. Tadesse, D. Review on the Role of Integrated Soil Fertility Management in Improving Maize Production in Ethiopia. J. Res. Dev. Manag. 2016, 23, 75-87.

32. Thilakarathna, M.S.; Manish, N.R. A Review of Nutrient Management Studies Involving Finger Millet in the Semi-Arid Tropics of Asia and Africa. Agronomy 2015, 5, 262-290. [CrossRef]

33. Devi, K.N.; Singh, T.B.; Athokpam, H.S.; Brajendra, N. Influence of inorganic, biological and organic manures on nodulation and yield of soybean (Glycine max Merril L.) and soil properties. Aust. J. Crop Sci. 2013, 7, $1407-1415$.

34. Adjei-Nsiah, S. Role of Pigeonpea Cultivation on Soil Fertility and Farming System Sustainability in Ghana. Int. J. Agron. 2012, 2012, 1-8. [CrossRef]

35. Abera, T.; Wegary, D.; Semu, E.; Debele, T.; Kim, H.; Resources, W.; Agricultural, A.; Showa, W.; Maize, I.; Conservation, G.; Program, A. Effects of soybean precursor crop and nitrogen rates on subsequent maize grain yield and nitrogen use efficiency at Bako, Ethiopia. Ethiop. J. Appl. Sci. Technol. 2015, 6, 1-23.

36. Friesen, D.K.; Palmer, A.F.E. Integrated Approaches to Higher Maize Productivity in the New Millennium Maize Program. In Proceedings of the Seventh Eastern and Southern Africa Regional Maize Conference, Nairobi, Kenya, 11-15 February 2002.

(C) 2017 by the authors. Licensee MDPI, Basel, Switzerland. This article is an open access article distributed under the terms and conditions of the Creative Commons Attribution (CC BY) license (http:/ / creativecommons.org/licenses/by/4.0/). 